\title{
DESAIN DAN IMPLEMENTASI DATA WAREHOUSE UNTUK PREDIKSI PENJUALAN PRODUK PADA TOKO MEKARSARI
}

\author{
I Putu Agus Eka Pratama ${ }^{1}$,I Gede Agus Pradipta ${ }^{2}$ \\ Program Studi Teknologi Informasi, Fakultas Tekik, Universitas Udayana \\ Jl. Raya Kampus Unud, Bukit Jimbaran, Badung, Bali, Indonesia \\ E-mail : eka.pratama@unud.ac.id, igedeaguspradipta@gmail.com
}

\begin{abstract}
ABSTRAK
Manusia tidak memiliki kemampuan untuk mengetahui apa yang akan terjadi di masa depan, seperti misalnya mengetahui barang yang laku dijual. Tetapi manusia dapat memprediksi sesuatu dengan melakukan analisa, misalnya memprediksi produk yang paling dicari atau dimiati di bulan depan atau tahun depan. Untuk dapat memprediksi hal tersebut dibutuhkan suatu ekosistem yang dapat membantu. Data warehouse dapat menjawab permasalahan tersebut. Data warehouse adalah sistem yang mengekstrasi, membersihkan, menyesuaikan, dan mengirim sumber data ke dalam penyimpanan data dimensi dan kemudian mendukung dan mengimplementasikan query dan analisis untuk tujuan pengambilan keputusan. Dengan data warehouse data historis suatu toko dapat dianalisa dan diketahui penjualan barang apa saja yang paling diminati oleh konsumen. Dengan mengetahui hal tersebut, pedagang dapat memprediksi barang apa saja yang dijual dan berapa jumlah barang yang harus di stok di tokonya sehingga dapat mengurangi tumpukan barang di gudang.
\end{abstract}

Kata Kunci: Data warehouse, Gudang Data, Business Intelligence

\section{PENDAHULUAN}

\subsection{Latar belakang masalah}

Mencari pekerjaan saat ini sangat sulit, apalagi jika tidak memiliki keahlian yang menjadi kebutuhan pasar. Hal tersebut mendorong masyarakat harus kreatif dalam membuat suatu usaha sehingga memiliki nilai jual. Salah satu aternatif usaha adalah mendirikan reatil.

Toko Mekarsari adalah salah satu retail yang berada di Dusun Banda, Desa Takmung, Kecamatan Banjarangkan, Kabupaten Klungkung. Toko Mekarsari dimiliki oleh perorangan dan tidak memiliki cabang. Produk yang dijual adalah kebutuhan sehari-hari, sehingga dapat toko ini dikategorikan sebagai toko serba ada.

Masalah yang sering diahapi oleh Toko Mekarsari adalah pelayanan kepada konsumen terhadap kebutuhan suatu produk. Salah satu masalah yang dihapai adalah stok barang habis saat ada permintaan dari konsumen dan barang yang diminta tidak dijual saat ada kosumen yang ingin membeli suatu produk. Masalah lainnya adalah kesulitan untuk menentukan jumlah stok barang yang disimpan karena kebutuhan konsumen akan suatu produk sulit diprediksi, sehingga perlu adanya pengambilan keputusan kapan untuk menyimpan stok suatu produk dalam jumlah besar atau sedikit. Kesulitan lainnya adalah menentukan barang yang harus dijual adalah masalah yang juga sering dihadapi. Barang yang dijual tidak selalu dibutuhkan oleh konsumen, tetapi terkadang ada waktu/musim di mana suatu barang sangat dicari, misalnya pakaian sekolah yang sangat dicari beberapa hari menjelang tahun ajaran baru dimulai.

\subsection{Rencana Penelitian}

Rencana pemecahan masalah yang digunakan untuk mengatasi permasalahan pada Toko Mekarsari adalah dengan penerapan teknologi data warehouse dengan menggunakan MySQL dan tools Talend Open Data Studio.

\subsection{Tujuan Penelitian}

Tujuan penelitian ini dilakukan adalah untuk membuat desain dan implementasi data warehouse yang diharapkan dapat membantu 
dalam prediksi pejualan suatu produk pada Toko Mekarsari. Diharapkan kedepannya tekologi data warehouse akan banyak digunakan untuk membantu pemilik usaha dalam pengambilan keputusan.

\subsection{Tinjauan Pustaka \\ 1.4.1 Data warehouse}

Data warehouse adalah sistem yang mengekstrasi, membersihkan, menyesuaikan, dan mengirim sumber data ke dalam penyimpanan data dimensi dan kemudian mendukung dan mengimplementasikan query dan analisis untuk tujuan pengambilan keputusan [5]. Pada umumnya, organisasi/perusahaan menyalin data dari sistem operasionalnya (seperti data dari database penjualan dan database SDM) ke gudang data menurut jadwal teratur, misalnya setiap malam atau setiap akhir minggu. Setelah itu, data tersebut dapat dilakukan query kompleks dan analisis untuk mendapatkan informasi yang diinginkan tanpa membebani sistem operasional [6].

Data warehouse memiliki karakteristik yang membuatnya berbeda dengan basis data yang lainnya. Terdapat empat karakteristik yang menjadi ciri khas dari data warehouse yaitu sebagai berikut [6].

1) Berorientasi kepada Subjek

Data warehouse berorientasi pada subjek karena data earehouse menawarkan informasi berupa subjek, bukannya operasi suatu perusahaan yang sedang berjalan. Subjek ini dapat berupa penjualan, pemasaran, distribusi, dan lain-lain [3].

Data warehouse tidak pernah berfokus pada operasi yang sedang berlangsung. Sebaliknya, data warehouse menekankan pada pemodelan dan analisis data untuk pengambilan keputusan. Ini juga memberikan pandangan yang sederhana dan ringkas seputar subjek tertentu dengan mengecualikan data yang tidak membantu untuk mendukung proses pengambilan keputusan [3].

\section{2) Data yang Dimiliki Terintegrasi}

Dalam data warehouse, integrasi berarti pembentukan unit pengukuran umum untuk semua data serupa dari basis data yang berbeda. Data juga perlu disimpan di data warehouse secara umum dan dapat diterima secara universal [3].

Data warehouse dikembangkan dengan mengintegrasikan data dari berbagai sumber seperti mainframe, database relasional, flat file, dan lain-lain. Selain itu, penamaan, format, dan pengkodean harus tetap konsisten [3].

Integrasi ini membantu dalam analisis data yang efektif. Konsistensi dalam konvensi penamaan, ukuran atribut, struktur pengkodean dan lain-lain harus dipastikan [3].

\section{3) Data yang Disimpan Bersifat Tetap}

Data warehouse juga bersifat non-volatile yang artinya data sebelumnya tidak terhapus ketika data baru dimasukkan di dalamnya. Data bersifat hanya baca dan diperbaharui secara berkala. Ini juga membantu menganalisa data historis dan memahami apa dan kapan terjadi [3].

Aktivitas seperti menghapus, memperbaharui, dan menyisipkan data yang dilakukan di lingkungan database transaksional dihilangkan dalam lingkungan data warehouse. Hanya dua jenis operasi data yang dilakukan di data warehouse yaitu pemuatan data dan akses data [3].

4) Dibuat Dalam Rentang Waktu Tertentu

Rentang waktu untuk data yang terdapat dalam data warehouse cukup luas dibandingkan dengan database transaksional. Data yang dikumpulkan dalam data warehouse dikumpulkan dari periode tertentu dan menawarkan informasi dari sudut pandang historis [3].

\subsubsection{Data Multi Dimensi}

Dasar pembuatan data warehouse adalah model multidimensi. Dengan pendekatan multi dimensi, data dapat dilihat dari beberapa sudut pandang yang berbeda, seperti pada sudut pandang waktu. Model data multidimensi terdiri dari entitas fakta dan entitas dimensi [4].

Tabel dimensi adalah perpsektif atau entitas penting yang dimiliki organisasi. Setiap dimensi memiliki kemungkinan satu tabel yang beraosiasi dengan tabel dimensi yang mendeskripsikan tabel itu sendiri. Dimensi akan berubah jika anailisis kebutuhan pengguna berubah. Dimensi mendefinisikan label yang membentuk isi laporan. Tabel dimensi berukuran lebih kecil daripada tabel fakta dan berisi data tidak numerik. Pada data warehouse, dimensi diibaratkan sebagai bangun ruang yang memiliki n-dimensi [4].

Tabel fakta adalah tabel yang berisi data numerik dan yang merupakan key dari tabel dimensi yang berelasi dengan tabel fakta. Data 
fakta cenderung stabil dan tidak berubah seiring waktu. Tabel fakta berukuran besar, memiliki jumlah baris sesuai dengan jumlah kombiasi nilai dimensi yang mungkin dan jumlah kolom sesuai dengan jumlah dimensi yang direpresentasikan [4].

Skema database berisi kumpulan entitas dan hubungan atarentitas. Sebuh data warehouse memerlukan skema yang ringkas dan berorientasi subjek yang dapat digunakan dalam OLAP. Tipe-tipe skema model data multidimensi adalah sebagai berikut [4].

\subsubsection{MySQL}

MySQL adalah sebuah perangkat lunak sistem manajemen basis data SQL (DBMS: Database Managemen System) yang multithread, multi-user, dan gratis di bawah lisensi GNU General Public License (GPL) [7].

Hal yang paling mendasar yang menjadikan MySQL pilihan utama sebagai database yang digunakan adalah karena MySQL menggunakan lisensi GPL dan multiplatform, sehingga tidak membutuhkan biaya besar dalam membuat aplikasi serta tidak harus tergantung pada OS Windows ataupun Linux karena dapat dijalankan pada kedua OS tersebut dan beberapa OS lainnya.

\subsubsection{Talend Open Studio Business Intelligence}

Talend adalah penyedia pertama perangkat lunak open source integrasi datad dengan salah satu produknya adalah Talend Open Studio Business Intelligence [1].

Talend Open Studio Business Intelligence digunakan untuk integrasi antara sistem operasional, serta untuk ETL (Extract, Transform, Load) untuk business intelligence, data warehousing, dan untuk migrasi data [1].

\section{METODOLOGI PENELITIAN}

\subsection{Rancangan Penelitian}

Penelitian pada jurnal ini dilakukan dengan metode seperti yang dilakukan oleh Wahyu Dwi Suryanto [2] dalam beberapa tahapan yang digambarkan pada Gambar 2.1.

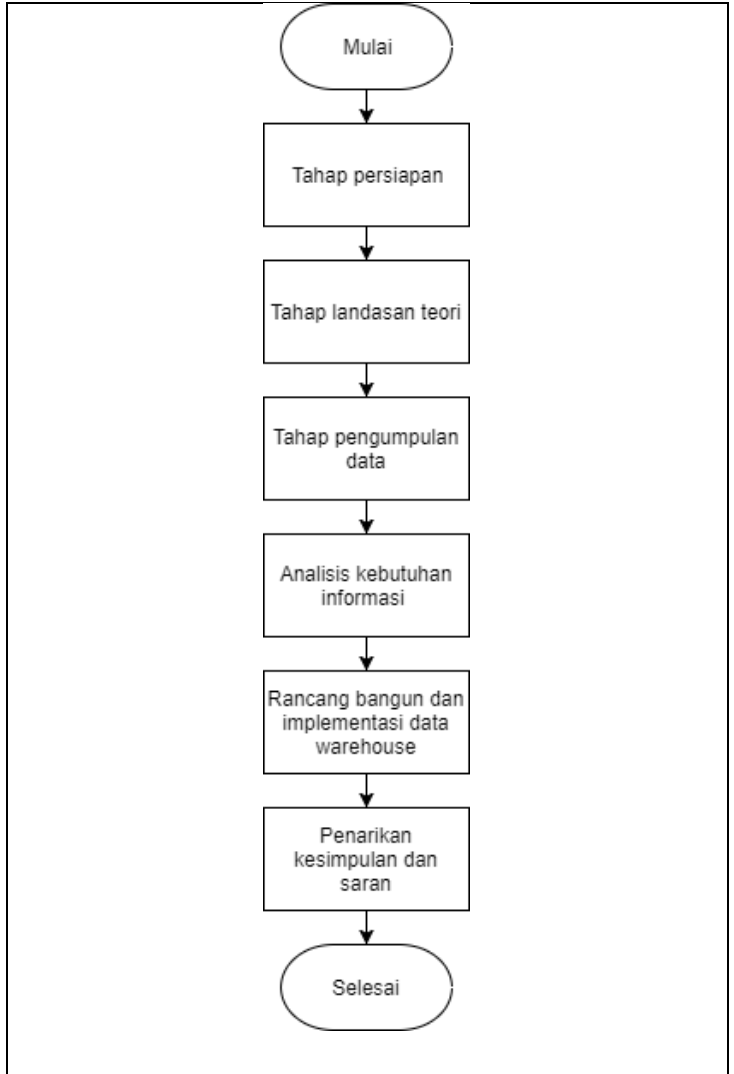

Gambar 2. 1 Rancangan Penelitian

Pada Gambar 2.1 digambarkan beberapa tahapan penelitian yang akan dijelaskan berikut ini.

1) Tahap Persiapan

Tahap ini merupakan tahap awal dalam penelitian yaitu dengan menentukan latar belakang, rencanan penelitian, dan tujuan penelitian.

2) Tahap Landasan Teori

Pada tahap ini dilakukan kajian teori yang berhubungan dengan penelitian yang dilakukan, seperti teori tentang data warehouse dan review jurnal yang berkaitan dengan penelitian yang dilakukan.

3) Tahap Pengumpulan Data

Tahap ini dilakukan pengumpulan data dengan beberapa cara yaitu:
a) Observasi
b) Wawancara
c) Studi literatur

4) Tahap Analisis Kebutuhan Informasi

Setelah tahap pengumpulan data, dilakukan analisis yang menghasilkan spesifikasi kebutuhan informasi yang dibutuhkan oleh user. 
5) Tahap Perancangan dan Implementasi

Pada tahap ini hal yang dilakukan adalah mendesain arsitektur fisik dan logikal data warehouse. Data yang bersumber dari database operasional akan diproses dengan konsep ETL (Extracts, Transformation, Loading).

6) Tahap Penarikan Kesimpulan dan Saran

Setelah data warehouse terbentuk, langkah selanjutnya adalah implementasi data warehouse sesuai dengan kebutuhan user. Dari hasil perancangan dan implementasi yang telah dilakukan, maka hasil akhir dari penelitian ini merupakan penarikan kesimpulan dan saran.

\section{HASIL DAN PEMBAHASAN}

\subsection{Persiapan Sumber Data}

Pada penelitian ini, Toko Mekarsari belum memiliki sistem yang telah menggunakan database untuk menangani transaksi operasionalnya. Hal tersebut menyebabkan kesulitan dalam menganalisis data karena semua transaksi tidak dicatat secara lengkap. Oleh karena itu, dibuatkan sebuah database yang menangani operasional toko sehingga mempermudah implementasi data warehouse selanjutnya. Database yang dibuat yang dibuat pada penelitian ini menggunakan DBMS MySQL. Skema database operasional yang dibuat dapat dilihat pada Gambar 3.1.

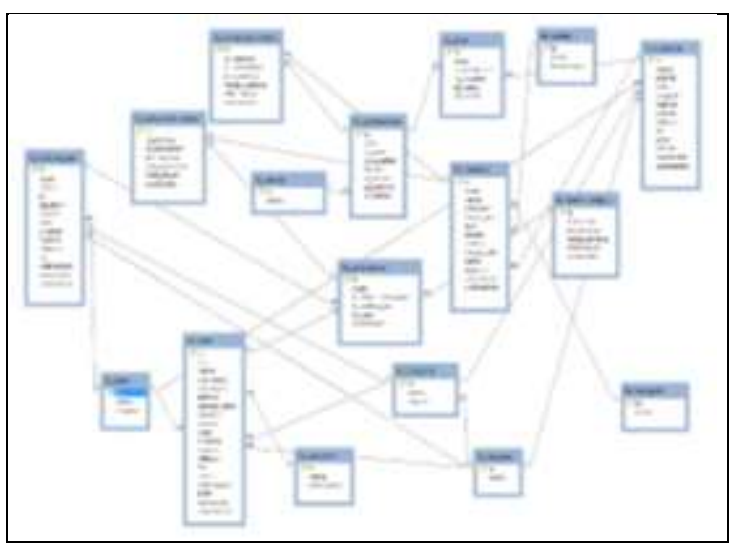

Gambar 3. 1 Skema database operasional

\subsection{Rancangan Data warehouse}

\section{1) Analisis Kebutuhan Informasi}

Analisis kebuthan informasi adalah tahap menganalisis informasi apa saja yang dibutuhkan oleh Toko Mekarsari untuk mendukung proses evaluasi dan analisis pengambilan keputusan penjualan. Informasi yang dibutuhkan oleh Toko Mekarsari untuk memprediksi barang yang akan dijual adalah informasi jumlah barang yang terjual pada bulan dan tahun tertentu.

\section{2) Memilih Grain}

Grain merupakan data dari calon fakta yang dapat dianalisis. Berdasarkan proses bisnis yang ada ditentukan grain yang menggambarkan tabel fakta sebagai berikut.

- Jumlah penjualan yang dilihat berdasarkan waktu, kategori barang, jenis barang, dan nama barang.

\section{3) Identifikasi Penyesuaian Dimensi}

Perancangan dimensi data warehouse yang dibuat dilakukan dengan membuat matriks antara grain dan dimensi yang disesuaikan dengan analisis kebutuhan dan digunakan sebagai dasar pembuatan data warehouse. Rancangan matriks yang dihasilkan dapat dilihat pada Tabel 3.1

Tabel 3. 1 Rancangan Matriks Proses Bisnis dan Dimensi

\begin{tabular}{|c|c|c|c|}
\hline Dimensi & 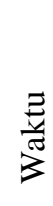 & 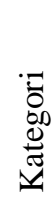 & 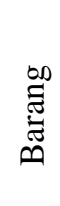 \\
\hline Penjualan & $\sqrt{ }$ & $\sqrt{ }$ & $\sqrt{ }$ \\
\hline
\end{tabular}

\section{4) Memilih Fakta}

Setelah menentukan dimensi yang digunakan, selanjutnya adalah memilih fakta yang digunakan dalam data warehouse. Masing-masing fakta memiliki data yang dapat dihitung dan nantinya dapat ditampilkan dalam bentuk laporan, grafik, atau diagram. Tabel Fakta yang akan digunakan adalah data penjualan dengan atribut meliputi waktu, id kategori, dan id barang, jml_barang, harga_barang, dan total_bayar.

\subsection{Implementasi Data warehouse \\ 1) Skema Data warehouse}

Setelah melakukan analisis dan identifikasi tabel dimensi dan tabel fakta yang akan digunakan, langkah selanjutnya adalah membuat database untuk data warehouse dengan menggunakan DBMS MySQL. Desain database data warehouse yang dibuat dapat dilihat Gambar 3.2. 


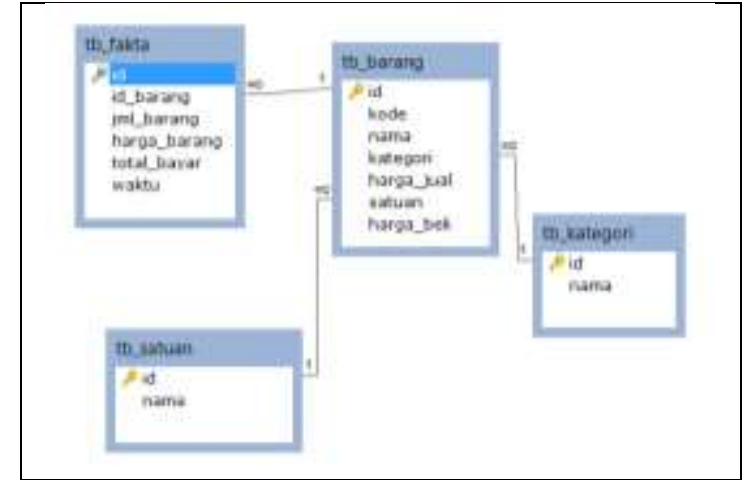

Gambar 3.2 Skema data warehouse Toko Mekarsari

\section{2) Proses ETL}

Setelah membuat database untuk data warehouse yang akan digunakan, selanjutnya adalah proses ETL dari database operasional ke database data warehouse dengan menggunakan tools Talend Open Studio Business Intelligence. Skema proses ETL yang dilakukan dapat dilihat pada Gambar 3.3.

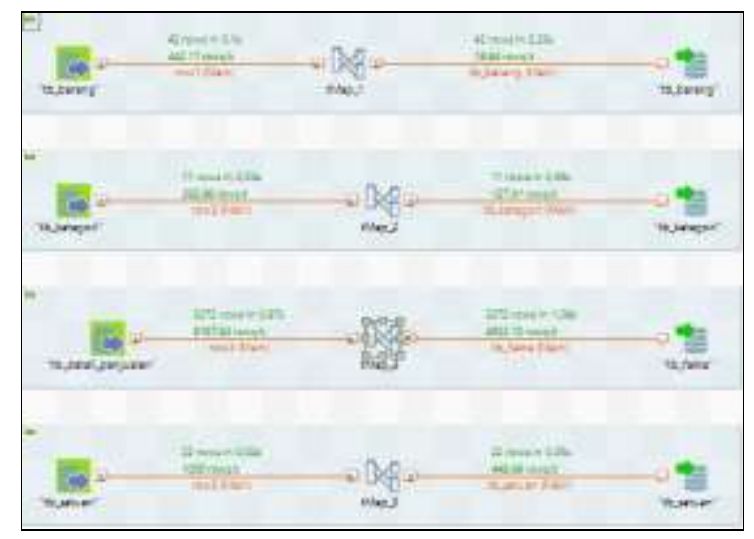

Gambar 3. 3 Proses ETL

\section{5) Proses OLAP (Online Analytical Processing)}

OLAP adalah salah satu cara dalam mengolah data pada data warehouse. Dengan OLAP, informasi yang dibutuhkan oleh user dapat diambil secara detail dari data warehouse.

Informasi yang dibutuhkan oleh Toko Mekarsari untuk melakukan prediksi barang yang harus dijual adalah informasi jumlah barang yang terjual baik perbulan maupun per tahun. Untuk mendapatkan informasi tersebut dilakukan dengan mengolah data pada data warehouse dengan query. Kode Program 3.1 adalah query yang digunakan untuk mendapatkan informasi jumlah barang yang terjual pada bedrasarkan nama barang tahun 2017.

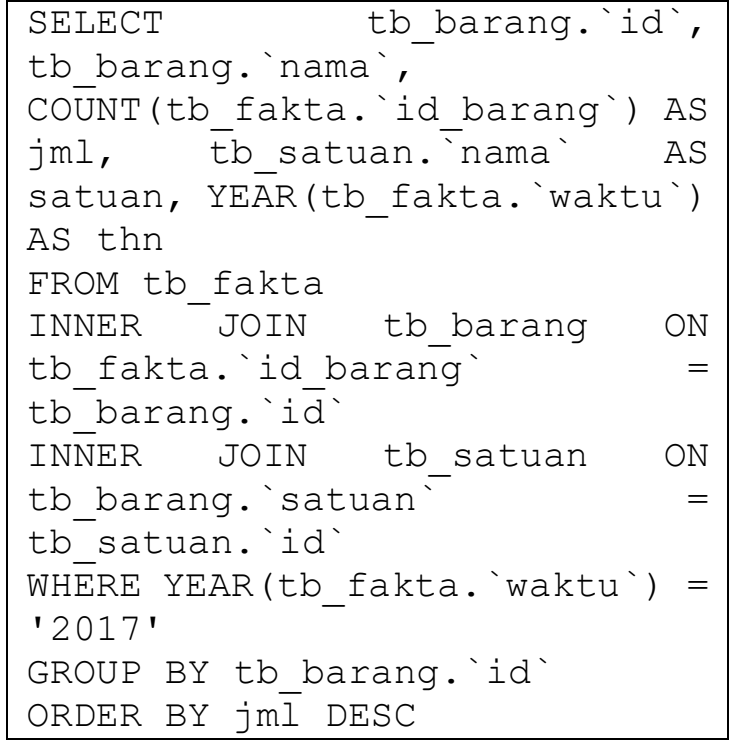

Kode Program 3. 1 Query untuk

menampilkan jumlah barang yang terjual bedasarkan nama barang pada tahun 2017

Kode Program 3.1 adalah query yang digunakan untuk menampilkan jumlah barang yang terjual bedrasarkan nama barang pada tahun 2017. Hasil query pada Kode Program 3.1 jika dijalankan dapat dilihat pada Gambar 3.4.

\begin{tabular}{|c|c|c|c|c|}
\hline id & nana & jal & satuan & thn \\
\hline 12 & Singlet. & 99 & bh & 2017 \\
\hline 6 & Roti Tawar Sari Rotí & 98 & biks & 2017 \\
\hline 8 & Chitato & 92 & bks & 2017 \\
\hline 32 & Kain pentersih & 92 & $1 \mathrm{br}$ & 2017 \\
\hline 14 & Cel ana olahraga (Training) & 90 & $\mathrm{bh}$ & 2017 \\
\hline 42 & Baterai ABC (per pasang) & $8 B$ & pag & 2017 \\
\hline 28 & Panci & 86 & $\mathrm{bh}^{\mathrm{y}}$ & 2017 \\
\hline 4 & Toh Gelas Botol & 86 & bt 1 & 2017 \\
\hline 36 & Pasta Gigi Pepsodent & 85 & $\mathrm{bh}$ & 2017 \\
\hline 23) & Tangkih & 84 & bks & 2017 \\
\hline 9 & Tango & 84 & bks & 2017 \\
\hline 15 & Kaos obleng & 83 & bh & 2017 \\
\hline 24 & Penek & 82 & bks & 2017 \\
\hline 10 & Beng-beng & 81 & biks & 2017 \\
\hline 26 & Kain Kasa mitan. & 80 & eter & 2017 \\
\hline 37 & Sabun Mika Garnier & 80 & $\mathrm{bh}$ & 2017 \\
\hline 1 & Aqua & 79 & bh & 2017 \\
\hline 27 & Kain Kasa Kaning & 79 & nter & 2017 \\
\hline 34 & Shampo Clear (Shachet) & 78 & $\mathrm{bh}$ & 2017 \\
\hline 17 & Pulpen Snowman & 78 & bh & 2017 \\
\hline 5 & Pocar i Sweat Kaleng & 77 & bh & 2017 \\
\hline 39 & Sapu & 76 & bh & 2017 \\
\hline 25 & Kain Kasa Putih & 75 & utr & 2017 \\
\hline 18 & Densil Steadler $2 \mathrm{~B}$ & 74 & bh & 2017 \\
\hline 33 & Sabun shinzut & 73 & bh & 2017 \\
\hline 11 & Kaos Kaki & 73 & psg & 2017 \\
\hline 41 & Cairan Pe1 Pexhersih & 72 & bel & 2017 \\
\hline 20 & Penghapus steadler & 72 & $\mathrm{bh}$ & 2017 \\
\hline 31 & $590 n$ & 72 & bh & 2017 \\
\hline 7 & Lays & 69 & bks & 2017 \\
\hline 40 & Kain Pel & 69 & bh & 2017 \\
\hline 3 & Teh Gelas & 69 & bh. & 2017 \\
\hline 30 & Sunl ichte & 69 & bet 1 & 2017 \\
\hline 21 & Bola Plastik & 67 & $\mathrm{bh}$ & 2017 \\
\hline 2 & Teh Pucik Botol & 67 & bel & 2017 \\
\hline 29 & wajan & 66 & $\mathrm{bh}$ & 2017 \\
\hline 22 & Dupa & 65 & bks & 2017 \\
\hline 38 & Kada & 62 & $\mathrm{bh}$ & 2017 \\
\hline 35 & sikat Gigi & 61 & bh & 2017 \\
\hline 16 & Buku Tulis sidu HVS 50 lbr & 58 & bh & 2017 \\
\hline 13 & Keneja & 57 & $\mathrm{bh}$ & 2017 \\
\hline 19 & Penggar is Besi & 55 & bh & 2017 \\
\hline
\end{tabular}

Gambar 3. 4 Jumlah barang yang terjual berdasarkan nama barang pada tahun 2017 .

Gambar 3.4 adalah hasil dari query pada Kode Program 3.1 setelah dijalankan. 
Ditampilkan daftar barang beserta jumlah baarang yang terjual pada tahun 2017.

Untuk mengetahui informasi mengenai jumlah barang yang terjual pada bulan tertentu bedrasarkan nama barang pada tahun 2017 dilakukan dengan menggunakan query pada Kode Program 3.2.

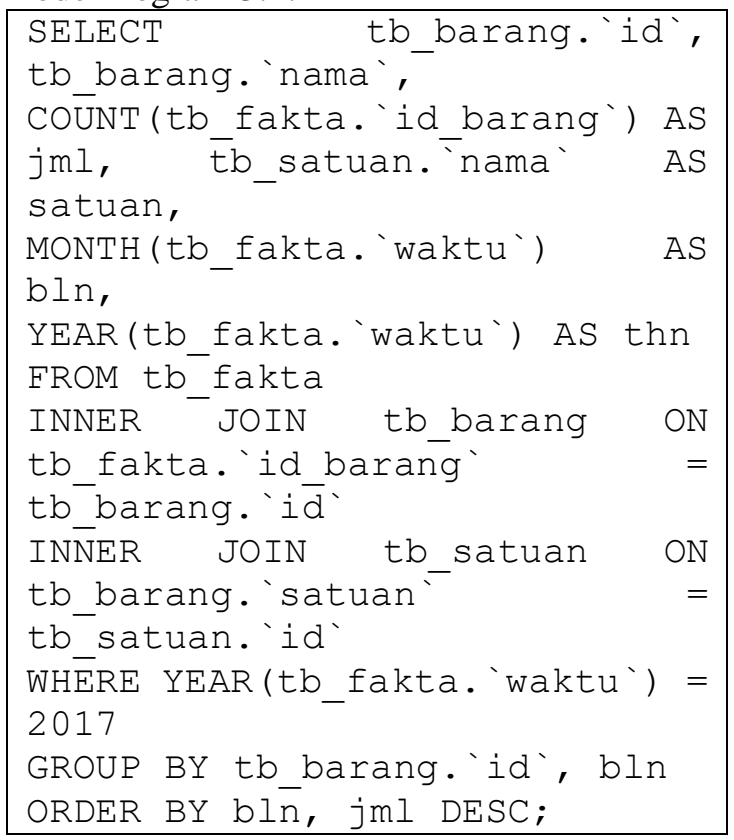

Kode Program 3. 2 Query untuk

menampilkan jumlah barang yang terjual pada bulan tertentu bedrasarkan nama barang pada tahun 2017

Kode Program 3.2 adalah query yang digunakan untuk menampilkan jumlah barang yang terjual pada bulan tertentu berdasarkan nama barang pada tahun 2017. Hasil query pada Kode Program 3.2 jika dijalankan dapat dilihat pada Gambar 3.4.

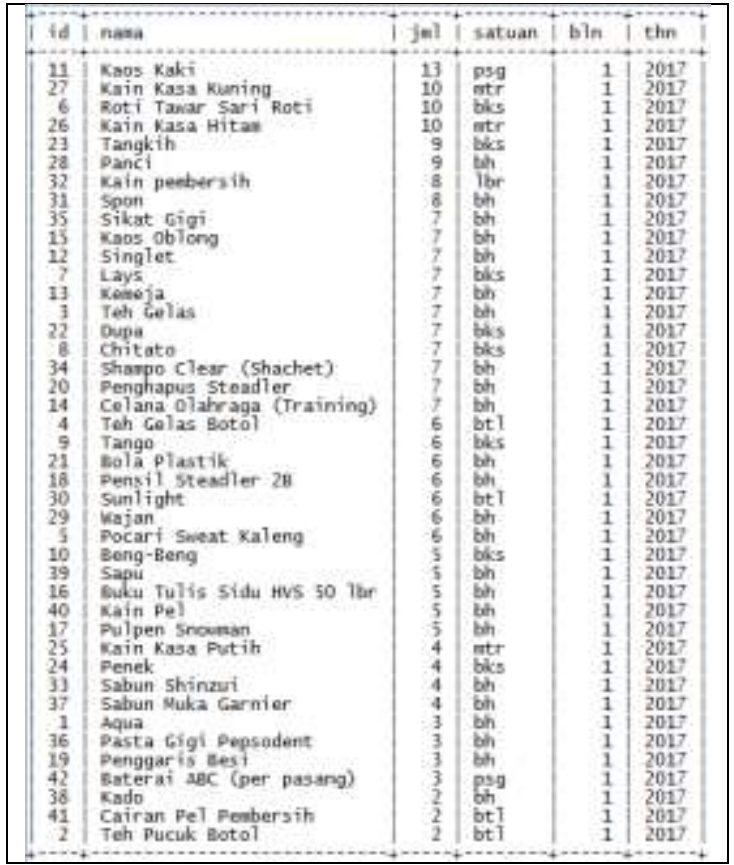

Gambar 3. 5 jumlah barang yang terjual pada bulan tertentu bedrasarkan nama barang pada tahun 2017

Gambar 3.5 ada;ah hasil dari query pada Kode Program 3.2 setelah dijalankan. Ditampilkan informasi mengenai jumlah barang yang terjual pada bulan 1 (Januari) tahun 2017.

Hasil query Kode Program 3.1 dan 3.2 dapat digunakan untuk memprediksi jumlah barang yang harus distok pada bulan tertentu. Misalnya pada bulan Januari 2017 kaos kaki adalah barang yang paling sering dibeli oleh konsumen Toko Mekarsari sehingga kaos kaki perlu disiapkan stok dengan jumlah yang lebih banyak.

\section{KESIMPULAN DAN SARAN \\ 4.1 Kesimpulan}

Berdasarkan hasil penelitian mengenai analisis desain dan implementasi data warehouse pada Toko Mekarsari, maka penulis dapat dapat mengambil kesimpulan sebagai berikut.

1) Desain dan implementasi data warehouse yang telah dilakukan dapat membantu pemilik usaha dalam proses pengambilan keputusan barang yang akan dijual dan disimpan dengan stok lebih.

2) Data didapatkan dari hasil transaksi penjualan yang terjadi pada Toko Mekarsari. Karena tidak ada pencatatan dengan sistem yang telah mengimplementasikan database, maka 
dibuatkan desain database untuk operasional Toko Mekarsari agar mempermudah dalam pengambilan data dan pemindahan data ke database data warehouse.

3) Proses integrasi data warehouse menggunakan konsep ETL.

4) Setelah melakukan integrasi data, analisis dilakukan dengan menggunakan query untuk mendapatkan informasi dari database data warehouse yang telah diimplementasikan.

\subsection{Saran}

Berdasarkan hasil penelitian dan keismpulan yang didapatkan, penulis dapat memberikan saran sebagai berikut.

1) Pemanfaatan data warehouse dapat membantu dalam proses bisnis dan analisa data, sehingga dapat membantu pemilik usaha untuk dasar pengambilan keputusan.

2) Pemanfaatan data warehouse tidak hanya untuk perusahaan besar, usaha rintisan pun dapat menerapkan data warehouse untuk mendukung perkembangan usaha.

\section{REFERENSI}

[1] datawarehouse4u.info. (2018, September 26). Talend Open Studio. Diambil kembali dari datawarehouse4u.info:

http://datawarehouse4u.info/Talend-OpenStudio.html

[2] Dwi Suryanto, W. (t.thn.). Pengembangan Data warehouse dan Aplikasi OLAP Data Tracer Study Alumni IPB Berbasis Web Menggunakan Microsoft Business Intelligence.

[3] Guru 99. (2018, September 18). Data warehouse Concepts, Architecture and Components. Diambil kembali dari Guru 99: https://www.guru99.com/data-warehousearchitecture.html

[4] Han, J., \& Kamber, M. (2012). Data Mining: Concepts and Techniques. Waltham, Waltham, USA: Morgan Kaufmann Publishers.

[5] Kimball, R., \& Caserta, J. (2004). The Data warehouse ETL Toolkit. Indianapolis: Wiley Publishing, Inc.

[6] Wikipedia. (2018, September 18). Gudang Data. Diambil kembali dari Wikipedia: https://id.wikipedia.org/wiki/Gudang_data

[7] Wikipedia. (2018, September 26). MySQL. Diambil kembali dari Wikipedia: https://id.wikipedia.org/wiki/MySQL 